\title{
Land use planning around protected areas: Case studies in four state parks in the Atlantic forest region of southeastern Brazil
}

\author{
Elizete Aparecida Checon Freitas Lima ${ }^{\mathrm{a}, *}$, Victor Eduardo Lima Ranieri ${ }^{\mathrm{b}}$ \\ a FEIS - Universidade Estadual Paulista "Julio de Mesquista Filho" - UNESP, Avenida Brasil, 56-Centro, - 15385-000 - Ilha Solteira, SP, Brazil \\ ${ }^{\mathrm{b}}$ EESC - Universidade de São Paulo - USP, Avenida Dr Carlos Botelho, Brazil
}

\section{A R T I C L E I N F O}

\section{Keywords:}

Buffer zone

Protected areas

Management plan

\begin{abstract}
A B S T R A C T
The creation of buffer zones (BZs) around protected areas (PAs) has been proposed as a way to conciliate the effective protection of biodiversity and human occupation in surrounding areas. In this study, we seek to discuss some of the challenges to effective buffer zones, focusing our attention on investigating two instruments used for the planning of these areas: the management plan of protected areas, and the municipal master plan. To achieve this, we evaluated the planning of land use around protected areas, as established in the management plans of four protected areas, located in southeastern Brazil, as well as in the master plans of the municipalities covered by these protected areas. We found that these management plans established recommendations rather than specific rules for the use of resources of the buffer zones. Additionally, we verified no uniformity between the master plans on the topic of municipal zoning in the BZs of the PAs studied: only five of the fourteen master plans surveyed delineated a zone around the protected area and defined guidelines for land use consistent with its protection. The results of this study indicate that the use of the buffer zone as an effective strategy for the management of protected areas requires a link between the PA managers and the local government responsible for land use planning, in order to facilitate the articulation between the management plan of the PA and the municipal master plan. Otherwise, the establishment of the buffer zone risks being only a symbolic action, with no practical effect on biodiversity conservation within the protected area.
\end{abstract}

\section{Introduction}

Conserving the biodiversity of protected areas (PAs) depends, to a considerable degree, upon how the areas surrounding them are utilized. Different uses of the land in the vicinity of a protected area negatively impact the protected area, due to interference in ecological processes (De Fries et al., 2010), putting the conservation of species in the area at risk (Gaston et al., 2008). Changing the land use around PAs also threatens these areas by isolating them in the landscape, which impacts biodiversity (De Fries et al., 2007). Wittemeyer et al. (2008) evidenced an increase in human occupation around protected areas when they analyzed the surroundings of 306 protected areas in 45 countries in Africa and Latin America and found that protected areas attracted human settlements, mainly because of the economic development projects associated with them. PAs located in developed regions and surrounded by heavily settled agro-pastoral landscapes also face challenges in retaining their natural vegetation (Marques et al., 2016), despite the application of restrictive legal instruments (Terra et al., 2014). As a consequence, several conservation approaches at the landscape level have been developed to improve the interaction of protected areas with their surroundings, among which is the buffer zone (BZ) model (Du et al., 2015).

The current literature on BZ has focused mainly on the social function of these areas and little attention has been given to the management of BZ (Perelló et al., 2012). Despite this, regulations for the creation and/or management of $\mathrm{BZ}$ have been reported in many countries (Ebregt and De Greve, 2000; Wallace et al., 2005; Paudel et al., 2007; Perelló et al., 2012; Weisse and Naughton-Treves, 2016), in a variety of political and socioeconomic contexts. It is important to examine the experiences of application of the $\mathrm{BZ}$ model with a view to improving this approach with regard to the interaction between PAs and their surroundings. We therefore seek to contribute to the discussion about the challenges of BZ implementation and management by presenting case studies on BZ planning in protected areas situated in a region of tropical forest in Brazil.

Brazilian legislation requires BZ creation for most categories of PAs and states that PA managers should establish specific rules for, and restrictions on, human activities in the $\mathrm{BZ}$ when the $\mathrm{PA}$ is created or

\footnotetext{
* Corresponding author at: Avenida Brasil, 56, Ilha Solteira, São Paulo, Brasil.

E-mail address: eacflima@bio.feis.unesp.br (E.A.C. Freitas Lima).
} 
during the creation of its management plan (Brasil, 2000). Furthermore, the municipalities share responsibility with PA managers for land use planning in the BZ of the PAs when they draft the master plans. Are the management plans and master plans fulfilling their roles in the planning and implementation of BZ? How is the interaction of the PA with its surroundings addressed in the management plans? To answer these questions, we evaluated the management plans of four state parks located in southeastern Brazil, and concurrently discussed how the municipalities affected by these PAs are planning the land use in the regions surrounding the PAs. We hope that the presentation of this Brazilian experience can contribute to the understanding and improvement of the management of BZs around PAs in other countries.

We begin by presenting the conceptual framework of buffer zone management, with particular attention to the legal aspects in Brazilian legislation and their use as a tool to integrate nature conservation into land use planning. This is followed by a section that details the selection of the case studies, then by a section that explains how the management plans and master plans were analyzed. The next two sections present the results of that analysis, with the aim of understanding: how the parks selected for this study are planning their BZs; which actions are planned in their management programs regarding the integration of the PA with its surroundings; and how the municipalities affected by these PAs are planning land use in the regions surrounding the PAs. In the final section, we present our conclusions regarding land use planning in the BZ of PAs and we emphasize the contribution of the work to increase the understanding about this subject.

\section{Conceptual framework}

The concept of a buffer zone around a protected area originated with the intent of protecting people and crops from animals leaving the area. The BZ concept was later broadened, influenced by the biosphere reserve model developed by UNESCO in the 1970s. At that time, BZs were created mainly with the intention of increasing the habitat area of the PA and protecting it from outside impacts (Ebregt and De Greve, 2000). More recently, the BZ concept has been mainly applied with the dual objectives of both protecting the natural area from negative human influences, and compensating the local populations that are impacted by the establishment of the protected areas (Ebregt and De Greve, 2000; Budhathoki, 2004; Wittemeyer et al., 2008).

The concept of zones of interaction was developed as an evolution of the BZ concept; it designates an area between a protected area and its surrounding landscape that includes a set of hydrological, ecological, and socioeconomic interactions (De Fries et al., 2010). A scientificallydelineated zone of interactions as part of a landscape approach for PAs (Palomo et al., 2014) could help identify the most essential places and types of land uses for protecting the integrity of the protected area (De Fries et al., 2010). The concept of PAs has itself evolved, from PAs being conceived of as islands, to networks, to landscape, to the more recent socioecological approach (Palomo et al., 2014); however, there are still many challenges to an effective BZ model of conservation planning (Weisse and Naughton-Treves, 2016).

Land use planning around the PAs can not always adequately protect them from the impacts of development pressures; therefore, new approaches are required to meet this challenge, such as the established of BZs (Fidelis and Sumares, 2008). BZ implementation, however, is a complex process involving many issues, including the existence of varied and often contradictory territorial planning instruments affecting PAs (Garcia and Revah, 2013), and a lack of harmonization between local governments and the agencies responsible for the management of PAs (Wallace et al., 2005). For example, the actions delineated in the management plans would need to be incorporated into municipal master plans (Neves, 2012), as well as into the plans of various public bodies, to ensure that they are implemented (Stockdale and Barker, 2009). The need to clearly define responsibilities for BZ planning and management (Wallace et al., 2005; Mehring and Stoll-
Klemann, 2011; Guimarães and Pellin, 2015; Weisse and NaughtonTreves, 2016) is another challenge to face in BZ implementation, especially when considering that the areas around the PAs are commonly third-party properties (Vitalli et al., 2009). In light of this, incorporating a socioecological approach into the planning and management of BZs has been recommended (Palomo et al., 2014), since the participation of local people contributes to their compliance with requirements (Ostrom and Nagendra, 2006; Andrade and Rhodes, 2012).

\section{Brazilian planning legal framework}

A BZ is defined in Federal Law 9985/2000 as the "area surrounding a conservation unit, ${ }^{1}$ where human activities are subject to specific rules and restrictions, in order to minimize negative impacts on conservation unit" (Brasil, 2000). There are guidelines for the design of the $\mathrm{BZ}$, which can be established when creating the PA or during the preparation of its management plan (Galante et al., 2002). A management plan is defined in the as "a technical document which, based on the general objectives of a conservation unit, establishes its zoning and the norms that should govern the use of the area and the management of natural resources, including the implementation of the fiscal structures necessary for the management of unit" (Article 2, Federal Law 9985/ 2000). It should cover "the area of the conservation unit, its buffer zone and ecological corridors, including measures to promote its integration into the economic and social life of neighboring communities" (Article 27, Federal Law 9985/2000). It is important to highlight that the BZ is located outside the conservation unit, in a territory that is not under the jurisdiction of the governmental agency responsible for the management of the conservation unit. However, the agency responsible for the conservation unit must establish specific rules regulating the occupation and use of the resources of the BZ (Brasil, 2000).

Another important legal guideline for BZ management is the Conama Resolution 428/2010, which regulates the licensing of activities with significant environment impact in the BZs of conservation units. Licenses for such activities can only be granted with the authorization of the governmental agency responsible for the management of the conservation unit. In the case of licensing activities that can affect the conservation units or their BZs, but which do not cause significant environment impact, the governmental agency responsible for management of the conservation units need only be informed (Brasil, 2010).

\section{Material and methods}

\subsection{Study area}

The area chosen for the study was the coastal zone of the state of São Paulo, located in a region of the Atlantic Forest. The Atlantic Forest is a global biodiversity hotspot, and was declared a biosphere reserve by UNESCO in 1991 (SOS Mata Atlântica, 2015). This area was chosen due to a number of characteristics, including the fact that it is the region of the state of São Paulo with the largest number of protected areas and the largest percentage of Atlantic Forest remnants. The region brings together a multitude of economic and social development characteristics, from small tourist towns to heavily industrialized cities.

\subsection{Selection of the case studies}

For the purposes of this study, we considered only conservation units belonging to the class of "strictly protected", that were situated in the terrestrial segment of the coastal zone of the state of São Paulo, and

\footnotetext{
${ }^{1}$ The conservation units are the protected area defined in the Federal Law 9985/2000 with the objective of ensuring biodiversity protection. They are divided into two main classes: strictly protected conservation units and sustainable use conservation units.
} 


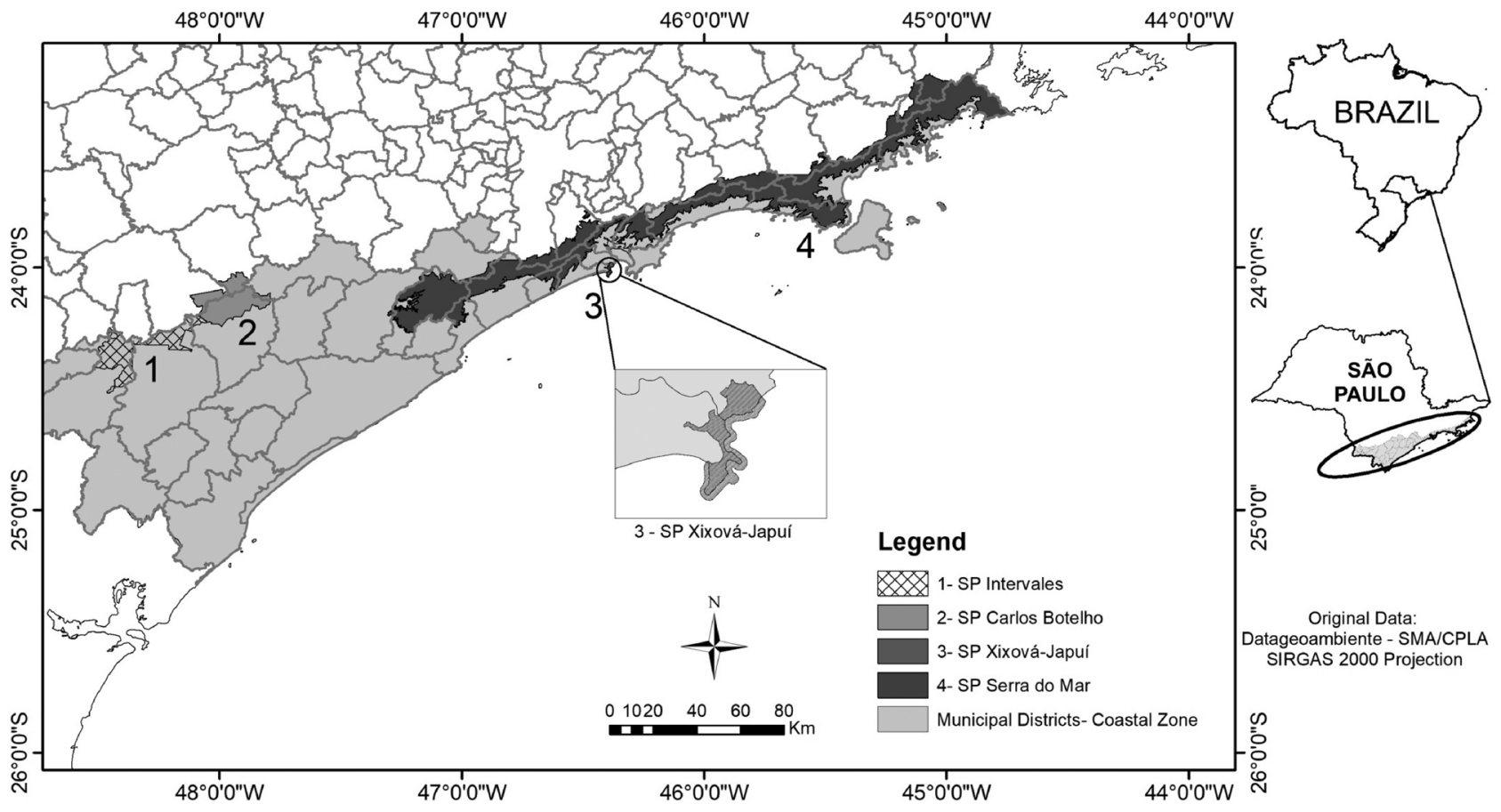

Fig. 1. Location of the conservation units selected in the coastal zone of state of São Paulo.

with a management plan approved by the State Environment Council. The presence of a management plan was checked in July 2015, by consulting the webpage of the Forest Foundation (Fundação Florestal), ${ }^{2}$ the environmental agency responsible for the management of protected areas in the state of São Paulo.

The conservation units selected were (Fig. 1): Serra do Mar State Park (SMSP), Xixová-Japuí State Park (XJSP), Carlos Botelho State Park (CBSP), and Intervales State Park (ISP). Among the categories of conservation units established by the National System of Conservation Units (NSCU), the basic aim of "parks" is "the preservation of natural ecosystems of major ecological relevance and scenic beauty, enabling the undertaking of scientific research and the development of educational activities, environmental appreciation and recreation in contact with nature and eco-tourism" (Brasil, 2000). The NSCU "parks" definition has a strong correlation with the definition of Category II of the IUCN classification of protected areas. The main characteristics of each of the conservation units are shown in Table 1.

\subsection{Methods}

The research method used was document analysis; the objects of analysis were the management plans of the selected conservation units (SMSP, XJSP, CBSP, ISP) and the master plans of the municipalities covered by these parks in the coastal zone of the state of São Paulo.

\subsection{Analysis of the management plans}

The management plans of the four parks were analyzed in two ways: (1) in terms of delineation and regulation of the BZ and (2) in terms of content relevant to interaction between the park and the surroundings. In relation to the first issue, the "zoning" section of the management plan was consulted, with the aim of verifying the existence of specific norms regulating the occupation and use of the resources of the BZ. It is necessary to emphasize that the BZ refers to an area located outside the conservation unit, but is subject to the rules established in the management plan of the conservation unit. In relation to the second issue, the management programs that integrated the conservation units' management plans were analyzed, with the goal of identifying the program's actions regarding the interaction of the PA with its surroundings. The criteria for analysis of the management plans were the guidelines contained in the Brazilian legislation regarding the planning of BZ in conservation units (Federal Law 9985/2000). This analysis sought to understand how the management plans fulfill the role, designated by Brazilian legislation, of guiding the planning of the buffer zone of the protected areas.

\subsection{Selection and analysis of the master plans}

Once the protected areas were selected, we referred to the web pages of the municipalities covered by these PAs in the study area, to attempt to find each municipality's master plans. It should be noted that there are other municipalities that also cover the SMSP, the CBSP and the ISP outside the coastal region of the state of São Paulo and that, therefore, were not part of the research. In turn, the XJSP is fully inserted in the study area. Brazilian legislation (Federal Law 10257/ 2001) establishes the requirement of preparation of master plans for municipalities of over 20,000 inhabitants (Brasil, 2001). This meant that some municipalities covered by the case study parks had no master plans and, therefore, had not been subject to analysis (Table 1).

The SMSP is covered by thirteen municipalities in the study area, of which twelve had their master plans analyzed (only the municipality of Pedro de Toledo did not have a master plan). Two of those municipalities also had the XJSP in their territory (Praia Grande and São Vicente). In addition, two other master plans were analyzed, referring to the municipalities of Sete Barras (covering CBSP and ISP) and Tapiraí (covering only the ISP). Table 1 shows the municipalities covered by each of the conservation units in the study area, with the laws and approval dates of their master plans. The master plans were analyzed, with the aim of identifying the municipal zoning regulations and the guidelines established for land use in the area surrounding the parks. 
Table 1

Information about of the conservation units (parks) and of the municipalities covered by them.

\begin{tabular}{|c|c|c|c|c|c|}
\hline Parks & Area (ha) & Creation of the park & Approval dates of management plans & Municipalities covered by Parks & Master plans of each municipalities \\
\hline \multirow[t]{13}{*}{ SMSP } & 332000 & Decree 10251 30/08/1977 & 2006 & Bertioga & Law 315/1998 \\
\hline & & & & Caraguatatuba & Law 42/2011 \\
\hline & & & & Cubatão & Law 2512/1998 \\
\hline & & & & Itanhaém & Law $30 / 2000$ \\
\hline & & & & Juquitiba & Law $1507 / 2007$ \\
\hline & & & & Mongaguá & Law 821/2013 \\
\hline & & & & Praia Grande & Law 473/2006 \\
\hline & & & & Pedro de Toledo & - \\
\hline & & & & Peruíbe & Law 100/2007 \\
\hline & & & & Santos & Law 821/2013i \\
\hline & & & & São Sebastião & Law 01/2014 \\
\hline & & & & São Vicente & Law 270/1999 \\
\hline & & & & Ubatuba & Law $711 / 1984$ \\
\hline \multirow[t]{2}{*}{ XJSP } & 901 & Decree 37536 27/09/1993 & 2010 & Praia Grande & Law 473/2006 \\
\hline & & & & São Vicente & Law 270/1999 \\
\hline \multirow[t]{2}{*}{ CBSP } & 37644 & Decree 19499 10/09/1982 & 2008 & Sete Barras & Law $1462 / 2008$ \\
\hline & & & & Tapiraí & Law 049/2011 \\
\hline \multirow[t]{3}{*}{ ISP } & 41704 & Decree 40135 08/06/1995 & 2008 & Eldorado & - \\
\hline & & & & Iporanga & - \\
\hline & & & & Sete Barras & Law1462/2008 \\
\hline
\end{tabular}

\section{Results}

\subsection{BZ planning in the management plans}

The BZ delimitation was presented in different ways among the management plans analyzed, from a very precise delimitation (XJSP) to one that only appeared as a proposal for later delimitation (ISP) (Table 2).The management plan of the conservation unit, as the main instrument for its management, should provide a precise delimitation of the $\mathrm{BZ}$, since this procedure establishes a territory subject to legal requirements regarding the environmental licensing of activities that cause environmental impact.

Similarly, the rules for use of resources and occupation of the BZ varied between plans, although in all cases they could be considered generic (Table 3). This fact has implications for the subsequent implementation of the BZ, since it is expected that the rules established for BZ planning in the PA management plan will be considered by those responsible for land use planning in the municipalities where the PA is located. However, Brazilian legislation does not clearly define who is responsible for the implementation and supervision of BZs.

\subsection{Social-environmental interactions in management plans}

Within the management plans, the Socio-environmental Interaction Program (SIP) was the principal program for presenting actions intended to integrate the protected area with its surroundings. The

Table 2

BZ delineation as established in the management plans.

\begin{tabular}{|c|c|}
\hline BZ Park & BZ delineation \\
\hline SMSP & $\begin{array}{l}\text { The BZ was described in approximate terms. The management plan do } \\
\text { not presents a map indicating the BZ area. }\end{array}$ \\
\hline XJSP & $\begin{array}{l}\text { The BZ was divided into three sectors with different characteristics. } \\
\text { The management plan presents a figure indicating the BZ area. }\end{array}$ \\
\hline CBSP & $\begin{array}{l}\text { The management plan presents a delineation of the BZ, but it has been } \\
\text { emphasized that the buffer zone would be presented in greater detail } \\
\text { when the Ecological and Economic Zoning of the municipalities was } \\
\text { carried out. } \\
\text { The management plan presents a figure indicating the BZ area. }\end{array}$ \\
\hline ISP & $\begin{array}{l}\text { The management plan presented a proposal for the further delimitation } \\
\text { of buffer zone, dividing it into many sectors, with details of current } \\
\text { land use and of the proposed land use for each sector. } \\
\text { The management plan presents some figures present the sketch of the } \\
\text { BZ area. }\end{array}$ \\
\hline
\end{tabular}

actions foreseen in the SIPs were similar among the management plans. All the actions were in accordance with the Federal Law that states that the plan must cover "the area of the conservation unit, its buffer zone and ecological corridors, including measures to promote their integration into the economic and social life of neighboring communities" (Article 27, Federal Law 9985/2000).The action "implementation and management of BZ" was planned in three of the analyzed SIPs, signaling a commitment to the realization of BZs on the part of those responsible for PA management. These three SIPs emphasized that BZ implementation will only be possible through cooperation with the local governments of the areas where BZs are located. They additionally state that for such a task, the role of the Management Council of the respective parks is essential: namely, working to mediate the relationship between park and society.

Our results indicate, therefore, that the management plans analyzed fulfilled their role in the planning of the buffer zone, and they assumed a more strategic planning feature in relation to the occupation and use of resources in these areas. This is reinforced by our observation that all management plans presented actions regarding the interaction of PA with its surroundings, emphasizing the importance of its articulation with local governments, especially during the construction of municipal master plans.

\subsection{BZs of parks in the master plans}

Among the twelve master plans analyzed of the municipalities in the study area covered by SMSP (see Table 1), only five delimited its boundaries and/or established guidelines focused on land use in the BZ of the park. In two municipal master plans (Praia Grande and Peruíbe), an explicit mention was made of the BZ of SMSP (Table 4).

In the master plan of the municipalities covered by XJSP (Praia Grande and São Vicente), a non aedificandi (do not build) area was delineated between the altimetric curves of five meters and $25 \mathrm{~m}$ around the perimeter of the park. This area covers part of the BZ of XJSP, preventing urban buildings and their associated impacts. The master plans of the municipalities that are covered by CBSP (Sete Barras and Tapiraí) and that covered by ISP (Sete Barras) did not indicate the boundary of a specific area around the parks, nor did they present guidelines for land use in the BZs.

\section{Discussion}

The delimitation of BZs according to Brazilian legislation creates a 
Table 3

Rules or recommendations for use of resources and occupation of the BZ indicated in the management plans

\begin{tabular}{|c|c|}
\hline BZ Park & Rules and recommendations \\
\hline SMSP & $\begin{array}{l}\text { The maintenance or ranges of native forest vegetation located between the Park and the areas destined to human activities subject to legal requirements regarding the } \\
\text { environmental licensing. } \\
\text { The indication of the location of legal reserves established by the forest law should take into account the connectivity with other vegetated protected areas. } \\
\text { Non - recommended uses: rural land subdivision, new urban land areas, cutting of vegetation continuous forests to Park, cultivation of genetically modified organisms } \\
\text { (GMO). }\end{array}$ \\
\hline XJSP & $\begin{array}{l}\text { The Industrial fishing and pair trawling are not permitted in the sector } 1 . \\
\text { The activities that should have SPXJ opinion on environmental licensing in the sector } 1 \text { and } 2 \text { are indicated. }\end{array}$ \\
\hline CBSP & $\begin{array}{l}\text { The SPCB should issue an opinion during the licensing of medium and large enterprises subject to legal requirements regarding the environmental licensing. } \\
\text { Non - recommended uses: rural land subdivision, new urban land areas, cutting of vegetation continuous forests to Park, cultivation of GMO. }\end{array}$ \\
\hline ISP & The specific land uses for each sector proposed in the BZ are indicated. \\
\hline
\end{tabular}

territory subject to specific requirements regarding the environmental licensing of activities that cause environmental impact around PAs. Therefore, it is expected that in the territories considered BZs, there will be greater control over the authorization of those activities, as was observed in the Peruvian Amazon by Weisse and Naughton-Treves (2016); this reinforces the importance of defining BZ limits during the preparation of the PA management plan. In our study, however, we found only one management plan that presented well-defined BZ limits (XJSP).

Regarding the regulation of BZs, all management plans studied contained generic rules for their occupation and use of their resources; similarly to the findings of other studies, the planning of the BZs assumed the character of recommendations rather than true rules (Perelló et al., 2012; Guimarães and Pellin,2015). This finding should be considered in light of Brazilian law, which stipulates shared responsibilities for planning the BZ between the managers of the PA and the local government. In this joint endeavor, one party (the PA managers) defines the rules for the occupation and use of resources in the BZ, and another (the local government) is responsible for planning land use in the municipal territory, including the BZ. In contrast to the planning of the $\mathrm{BZ}$, the legislation does not clearly define responsibilities for BZ implementation and management. In other studies, this has been identified as a factor that limits the effectiveness of BZs (Wallace et al., 2005; Mehring and Stoll-Klemann, 2011; Weisse and Naughton-Treves, 2016). In this sense, the management plans have adopted a strategic approach to BZ planning, in accordance with guidelines of the Brazilian Environmental Institute (Ibama) (Galante et al., 2002) for the elaboration of the park management plan. Thus, the management plan that has a mandatory character with respect to the internal zoning of the protected area would have a strategic character, in relation to the $\mathrm{BZ}$ planning.

The role of PA Management Councils in the relationship between the managers of the PA, the local government, and residents surrounding the PA was highlighted in the management plans, with some actions proposed to improve the councils. The plans that were analyzed placed value on societal participation in management of the PA, including the BZ. This fact is especially important considering that the areas around the PAs are commonly properties owned by third parties
(Vitalli et al., 2009). In addition, participation of local people in PA management shows to improve the compliance of local populations with PA requirements (Ostrom and Nagendra, 2006; Mehring and StollKlemann, 2011; Andrade and Rhodes, 2012), and can also reduce existing and potential conflicts between PA managers and local populations (Sodhi et al., 2010).

We found no uniformity between the master plans in relation to municipal zoning around protected areas, especially in the BZs. Only five of the fourteen master plans surveyed delineated a zone around the protected area and/or defined guidelines for land use consistent with its protection. It is important to emphasize that to increase compliance with the rules relating to the use of resources in BZs, their incorporation into master plans would be required, due to local governments' increased capacity for inspection and control, coupled with their expertise in land use planning (Neves, 2012). On the other hand, land use planning around the Pas is not always adequate to protect them from the impacts of development pressures (Fidelis and Sumares, 2008). The incorporation of a Strategic Environmental Assessment in the preparation of PA management plans and municipal master plans could facilitate coordination among these planning instruments (Garcia and Revah, 2013) and improve their quality (Stockdale and Barker, 2009; Esteves and Souza, 2014), which would in turn contribute to improving land use planning around the PAs.

\section{Conclusions}

The management plans analyzed fulfilled their role in the planning of the buffer zone and they assumed a more strategic planning feature in relation to the occupation and use of resources in these areas. They established generic rules for the use of resources of the BZs, as well as guidelines for greater integration of the PA with its surroundings. Within these guidelines, coordination between the PA managers and local governments should be emphasized in order to ensure compatibility between the land use legislation and the specific rules for occupation and use of the resources of the BZ, as established in the PA management plan. Other guidelines mentioned in the management plans aimed to encourage greater integration between the park and the people living in its surrounding areas, including fostering sustainable

Table 4

Guidelines for BZ SPSM defined in the municipal zoning established in the master plans.

\begin{tabular}{|c|c|}
\hline Master plan & Guidelines - municipal zoning \\
\hline Caraguatatuba & Delimit a 100-m transition fringe between the SPSM and the urbanized area. \\
\hline São Sebastião & $\begin{array}{l}\text { Promote the sustainable use of an enveloping transition fringe around the limits of SPSM, with tourist activities as a way of guaranteeing the protection of the } \\
\text { SPSM. }\end{array}$ \\
\hline Praia Grande & $\begin{array}{l}\text { Allocate a transition area for urban support and eco-tourism, with low occupation intensity and in accordance with the guidelines for BZ established in the SPSM } \\
\text { management plan. }\end{array}$ \\
\hline Mongaguá & $\begin{array}{l}\text { Consolidate in an area delimited around the SPSM the tendency of conservation in rural areas through leisure farmhouses, as well as supporting the preservation } \\
\text { of the Park. }\end{array}$ \\
\hline Peruíbe & $\begin{array}{l}\text { Delimit an area in correspondence to BZ SPSM with the objective of make agricultural and rural tourist usage compatible with the environmental needs of the } \\
\text { SPSM BZ. }\end{array}$ \\
\hline
\end{tabular}


activities in the BZ and the establishment of Park Management Councils. It is important, however, that the planned actions are implemented and their results evaluated, in a continuous monitoring process, to reveal whether the envisaged actions did in fact result in more effective protection of the conservation unit.

The results of this study indicate that only five of the fourteen master plans we analyzed delineated a zone around the PA and defined guidelines for land use consistent with its protection. We therefore emphasize in our discussion that the use of the BZ as a strategy for the management of protected areas requires a link between the PA managers and the local government, in order to facilitate the articulation between the management plan of the PA and the municipal master plan. Otherwise, the establishment of a BZ risks being only a symbolic action, with no practical effect on biodiversity conservation within the PA.

Although the results presented in our study can not be extended to the entire set of BZs of PAs, they undoubtedly represent an important picture of land use planning around them, especially in biodiversity hotspots and Biosphere Reserves with significant human occupation, such as the coastal region of the state of São Paulo. In that sense, we hope to have contributed to increase the understanding of important aspects about the use of BZ as a strategy for the management of PAs in predominantly anthropic landscapes.

\section{Acknowledgement}

This research did not receive any specific grant from funding agencies in the public, commercial, or not-for-profit sectors. We would like to thank Érica Mendonça for the elaboration of the figures in this work.

\section{References}

Andrade, G.S.M., Rhodes, J.R., 2012. Protected areas and local communities: an inevitable partnership toward successful conservation strategies? Ecol. Soc. 17, 14. http://dx.doi.org/10.5751/ES-05216-170414.

Brasil. Presidência da República. Casa Civil, 2000. Lei 9985, de 18 de junho de 2000. http://www.planalto.gov.br/ccivil 03/Leis/L9985.htm.

Brasil. Presidência da República. Casa Civil, 2001. Lei 10257 (Estatuto das Cidades), de 10 de julho de 2001. http://www.planalto.gov.br/ccivil_03/leis/LEIS_2001/L10257. htm.

Brasil. Conselho Nacional de Meio Ambiente-Conama, 2010. Resolução Conama 428, de17 de dezembro de 2010. http://www.mma.gov.br/port/conama/.

Budhathoki, P., 2004. Linking communities with conservation in developing countries: buffer zone management initiatives in Nepal. Oryx 38, 334-341. http://dx.doi.org/ 10.1017/S0030605304000584.

De Fries, R., Hansen, A., Turner, B.L., Reid, R., Liu, J., 2007. Land use change around protected areas: management to balance human needs and ecological function. Ecol. Appl. 17, 1031-1038. http://dx.doi.org/10.1890/05-1111.

De Fries, R., Karanth, K.K., Pareeth, S., 2010. Interactions between protected areas and their surroundings in human-dominated tropical landscapes. Biol. Conserv. 143, 2870-2880. http://dx.doi.org/10.1016/j.biocon.2010.02.010.

Du, Wenwu, Penabaz-Wiley, S.M., Njeru, A.M., Kinoshita, I., 2015. Models and approaches for integrating protected areas with their surroundings: a review of the literature. Sustainability 7, 8151-8177. http://dx.doi.org/10.3390/su7078151.

Ebregt, A., De Greve, P., 2000. Buffer Zones and Their Management. Theme Studies Series, 5. National Reference Centre for Nature Management International
Agricultural Centre, Wageningen, The Netherlands. https://pdfs.semanticscholar. org/5d63/d60d5479deaa91867f6d084d3e4ad7a34f2f.pdf.

Esteves, A.O., Souza, M.S., 2014. Avaliação Ambiental Estratégica e as Áreas de Proteção Ambiental. Engenharia Sanitária e Ambiental, Edição Especial 77-86. http://dx.doi. org/10.1590/S1413-41522014019010000443.

Fidelis, T., Sumares, D., 2008. Nature conservation and development control in the Portuguese planning system: a new impetus against old praxis? Eur. Environ. 18, 298-311. http://dx.doi.org/10.1002/eet487.

Galante, M.L.V., Bezerra, M.M.L., Menezes, E.O., 2002. Roteiro Metodológico de planejamento. Parque Nacional, Reserva Biológica, Estação Ecológica. Brasília. IBAMA. http://www.icmbio.gov.br/portal/images/stories/imgs-unidades-coservacao/ roteiroparna.pdf.

Garcia, D.A.D., Revah, L.O., 2013. La Reserva de la Biosfera Alto Golfo de California y Delta del Río Colorado: planeación territorial. Región y Sociedad 25, 57-85. https:// www.colson.edu.mx:4433/Revista/Articulos/58/3Alejandra.pdf.

Gaston, K.J., Jackson, S.F., Cantú-Salazar, L., Cruz-Pinón, G., 2008. The ecological performance of protected areas. Annu. Rev. Ecol. Evol. Syst. 39, 93-113. http://dx.doi. org/10.1146/annurev.ecolsys.39.110/07.173529.

Guimarães, E., Pellin, A., 2015. BiodiverCidade. Matrix, São Paulo, pp. 200.

Marques, A.A.B.M., Schneider, M., Peres, C.A., 2016. Human population and socioeconomic modulators of conservation performance in 788 Amazonian and Atlantic forest reserves. PeerJ 4, e2206. http://dx.doi.org/10.7717/peerj.2206.

Mehring, M., Stoll-Klemann, S., 2011. How effective is the buffer zone? Linking institutional processes with satellite images from a case study in the lore Lindu forest biosphere reserve, Indonesia. Ecol. Soc. 16, 3. http://dx.doi.org/10.5751/ES-04349160403.

Neves, E.M.S.C., 2012. Política ambiental, municípios e cooperação intergovernamental no Brasil. Estudos Avançados 26. http://dx.doi.org/10.1590/S010340142012000100010.

Ostrom, E., Nagendra, H., 2006. Insights on linking forests, trees, and people from the air, on the ground, and in the laboratory. PNAS 103, 19224-19231. http://dx.doi.org/10 1073/pnas.0607962103.

Palomo, I., Montes, C., Martin-López, B., Gonzàlez, J.A., Garcia-Llorente, M., Alcorlo, P., Mora, M.R.G., 2014. Incorporating the social-ecological approach in protected areas in the anthropocene. Bioscience 64, 181-191. http://dx.doi.org/10.1093/biosci/ bit033.

Paudel, N.S., Budhathoki, P., Sharma, U.R., 2007. Buffer zones: new frontiers for participatory conservation? J. For. Livelihood 6, 44-53. http://www.nepjol.info/index. php/JFL/article/view/2324.

Perelló, L.F.C., Guadagnin, D.L., Maltchik, L., Santos, J.E., 2012. Ecological, legal, and methodological principles for planning buffer zones. Braz. J. Nat. Conserv. 10, 3-11. http://dx.doi.org/10.4322/natcon.2012.002.

SOS Mata Atlântica 2015 https://www.sosma.org.br/projeto/planos-de-mata-atlantica/.

Sodhi, N.S., Lee, T.M., Sekercioglu, C.H., Webb, E.L., Prawiradilaga, D.M., Lohman, D.J., Pierce, N.E., Diesmos, A.C., Rao, M., Ehrlich, P.R., 2010. Local people value environmental services provided by forested parks. Biodivers. Conserv. 19, 1175-1188. http://dx.doi.org/10.1007/s10531-009-9745-9.

Stockdale, A., Barker, A., 2009. Sustainability and the multifunctional landscape: an assessment of approaches to planning and management in the Cairngorms National Park. Land Use Policy 26, 479-492. http://dx.doi.org/10.1016/j.landusepol.2008. 07.001.

Terra, T.N., Santos, R.F., Costa, D.C., 2014. Land use changes in protected areas and their future: the legal effectiveness of landscape protection. Land Use Policy 38, 378-387. http://dx.doi.org/10.1016/j.landusepol.2013.12.003.

Vitalli, P.L., Zakia, M.J.B., Durigan, G., 2009. Considerações sobre a legislação correlata à zona tampão de Unidades de Conservação no Brasil. Ambiente e Sociedade 12, 87-92. http://www.scielo.br/pdf/asoc/v12n1/v12n1a06.pdf.

Wallace, G.N., Barborak, J.R., Mac Farland, C., 2005. Land use planning and regulation in and around protected areas: a study of legal frameworks, best practices and capacity building needs in Mexico and Central America. Braz. J. Nat. Conserv. 3, 147-167.

Weisse, M.J., Naughton-Treves, L.C., 2016. Environmental Management. http://dx.doi. org /10.1007/s00267-016-0709-z.

Wittemeyer, G., Elsen, P., Bean, W.T., Coleman, A., Burton, O., Brashares, J.S., 2008. Accelerated human population growth at protected area edges. Science 321, 123-126. http://dx.doi.org/10.1126/science.1158900. 